\title{
Research participants
}

$\mathrm{T}$ HIS IS NOT an exhaustive list of all the people who appear in the book. It introduces the key biographical details of the main research participants I worked with in Napoli. Their lives and experiences are told in richer detail throughout the chapters. With the exception of Omar, Ciro and Titty, all names used are pseudonyms.

\section{Via Bologna market}

Gennaro: a middle-aged Neapolitan man who sold socks and underwear from his stall on Via Bologna. He had run a stall in the Piazza Garibaldi area since the early 1990s, and prior to that he owned a shop. He was politically active in local movements for the unemployed.

Alfonso: He had a knick-knack stall next to Gennaro's stall. He was also an activist.

Comfort: She was a middle-aged Nigerian woman who had been running a market stall in the Piazza Garibaldi area since the 1990s and had known Gennaro for a long time. Her stall used to sell wax cloth but, when I met her, she mostly sold Chinese-manufactured clothing. She was also an activist.

Elage: A middle-aged Senegalese man. His stall sold Kola Nuts, tea and toiletries for an African clientele.

Moussa: A young Malian man who was friends with Gennaro. He shared Gennaro's storage depot with him.

Riccardo: A middle-aged Neapolitan man who owned a souvenir shop on Via Bologna.

Serigne: A middle-aged Senegalese man who ran a stall at the market and was its informal market manager. He used to work for Riccardo and had maintained a strong friendship with him. 
Sohna: She was Serigne's wife. She ran a mobile food stall that sold sandwiches to stall holders and market customers. The stall was based outside Riccardo's shop. Omar: A Senegalese cultural mediator and activist who introduced me to the vendors at Via Bologna and on irregular pitches across the city.

Ibra: A Senegalese man in his early thirties who sold Italian designer hats from a cloth on the pavement on one of the main roads in the city centre.

Giovanni: He owned the grocery shop behind Ibra's stall. The two men were good friends.

Salvatore: A Neapolitan man in his thirties. He worked as a doorman for the apartment block next to Ibra's stall.

Modou: A Senegalese man in his early thirties. His stall sold contraband designer handbags and wallets. He also shipped packages abroad to Northern Italy and France.

Carlo: A Neapolitan man in his early sixties. He lived in the area and had been friends with Modou since he first put his pitch on the street.

Ku: A Chinese man in his late twenties. He ran an electronics stall on one of the major roads in the city centre. He was married and had two children. His family (including wife and mother- and father-in-law) ran a shop in Pompei, also selling electronic goods.

\section{Poggioreale market}

$$
\text { Eddy Pell stall }
$$

Ciro and Titti: They were a married Neapolitan couple that ran a business called Eddy Pell, selling Italian designer branded bags and purses. They had a market stall at Poggioreale, and a shop in the Piazza Mercato neighbourhood of Napoli.

\section{Peppe's Bags stall}

Alessandro: A Neapolitan man in his thirties who owned this stall with his dad, Peppe. They stall sold Italian designer bags as well as Chinese imports.

Peppe: He was Alessandro's dad. The stall was part of a family business, with a shop in the city centre. 